\title{
A COMPUTER CODE TO ASSESS ACCIDENTAL POLLUTANT RELEASES
}

\author{
M. M. PENDERGAST \\ J. C. HUANG
}

\section{TIS FILE \\ RECORD COPY}

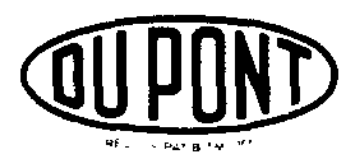

E. I. du Pont de Nemours \& Co. Savannah River Laboratory

Aiken, SC 29808 
This report was prepared as an account of work sponsored by the United States Government. Neither the United States nor the United States Depertment of Energy, nor any of their employees, make any warrenty, express or implied, or assumes any legal liability or responsibility for the eccuracy, completeness, or usefulness of any information, apparatus, product, or process disclosed, or represents that its use would not infringe privately owned rights. Reference herein to any specific commercial pro. duct, process, or service by trade name, mark, manufacturer, or otherwise does not necessarily constitute or imply its endorsement, recommendation, or favorine by the United States Government or any agency thereof. The views and opinions of authors expressed herein do not necessarily state or reflect those of the United States Government or any agency thereof.

Printed in the United States of America
Available from
National Technical Information Service
U. S. Department of Commerce
5285 Port Royal Road
Springtield, Virginia 22161
Price: Printed Copy A02: Microfiche A01




\section{A COMPUTER CODE TO ASSESS ACCIDENTAL POLLUTANT RELEASES}

by

M. M. Pendergast and J. C. Huang

Approved by

T. V. Crawford, Research Manager

Environmenta 1 Transport Division

Publication Date: July 1980

E. I. du Pont de Nemours \& Co. Savannah River Laboratory Aiken, SC 29808

PREPARED FOA THE U. S. DEPARTMENT OF ENERGY UNDER CONTRACT DE-AC09.76SRO0001 


\section{ABSTRACT}

A computer code has been developed to calculate the cumulative frequency distributions of relative concentrations of an air pollutant following an accidental release from a stack or from a building penetration such as a vent. The calculations of relative concentration are based on the Gaussian plume equations. The meteorological data used for the calculation are in the form of joint frequency distributions of wind and atmospheric stability. 


\section{CONTENTS}

Introduction 5

Equations for Calculating Relative Concentrations 6

Stack Releases 6

Releases Through Building Penetrations 9

Selection of $X / Q$ for a Postulated Release 11

Maximum Sector $X / Q 11$

$5 \%$ Overal1 Site $X / Q 11$

$\chi / Q$ for Calculating Postulated Events 11

Input Data 11

Meteorology 11

Topography 13

Distance to Boundary 13

Output 15

References 21 


\section{INTRODUCTION}

A1l applications for a license to construct and operate a nuclear facility must include an assessment appraisal of the environmental consequence of an accident at the proposed site. The results of this assessment can be used to alter design of the facility. The most common change is increasing the height of the effluent release. The Nuclear Regulatory Commission (NRC) has supplied guidance for this assessment for Nuclear Power Plants (Regulatory Guide 1.145). ${ }^{1}$ This report describes computer coding of an NRC model for assessing accidents based on this guide and gives examples of input and output data.

The accidental release assessment model is based on five equations adapted from the Gaussian plume model. Two of the equations are used to calculate relative concentrations from stack releases. The remaining equations are used to calculate relative concentrations from releases through vents or building penetrations. The output of the model is a single value for the relative concentration selected from the cumulative frequency distribution of relative concentration at the site boundary. The input data used to calculate the relative concentration are the joint frequency distribution of wind and atmospheric stability, topography, stack height, building dimensions, and distance to the site boundaries. 


\section{EQUATIONS FOR CALCULATING RELATIVE CONCENTRATIONS}

\section{Stack Releases}

Equations 1 and 2 are for calculating releases from a release point at least 2-1/2 times the height of adjacent solid structures.

$$
\begin{aligned}
& X / Q=\frac{1}{\pi \bar{u}_{h_{s}} \sigma_{y} \sigma_{z}} \exp \left[h_{e}{ }^{2} / 2 \sigma_{z}{ }^{2}\right] \\
& X / Q=\frac{1}{2 \pi \bar{u}_{h_{e} \sigma_{y} h_{e}}}\left(h_{e}>0\right)
\end{aligned}
$$

where

$$
\begin{aligned}
X / Q= & \text { the centerline relative concentration, } \mathrm{sec} / \mathrm{m}^{3} \\
\bar{u}_{h_{s}}= & \text { the wind speed at the release height } h_{s}, \mathrm{~m} / \mathrm{sec} \\
\bar{u}_{h_{e}=} & \text { the wind speed at height } h_{e}, \mathrm{~m} / \mathrm{sec} \\
\sigma_{y}= & \text { the standard deviation of plume concentration in the } \\
& \text { crosswind direction (see Figure } 1 \text { ) } \\
\sigma_{z}= & \text { the standard deviation of plume concentration in } \\
& \text { the vertical direction (see Figure } 2 \text { ); } \sigma_{z} \text { is } \\
& \text { constrained so as not to exceed } 80 \% \text { of the depth } \\
& \text { of the mixing } 1 \text { ayer. } \\
h_{e}= & \text { the effective stack height, m; } h_{e}=h_{s}-h_{t}, \\
& \text { where } h_{s} \text { is the height of the stack above plant } \\
& \text { grade, and ht is the maximum terrain height above } \\
& \text { plant grade between the release point and the } \\
& \text { point for which the concentrations are calculated } \\
& \text { (when ht exceeds } h_{s} \text { the value of } h_{e} \text { is set to } \\
& \text { zero). }
\end{aligned}
$$

Equation 1 represents the maximum plume centerline relative concentration at ground level during nonfumigation conditions, and Equation 2 gives this concentration during fumigation conditions. The concentrations under fumigation conditions cannot be higher than those produced by nonfumigation, stable atmospheric conditions with $h_{e}=0$. 


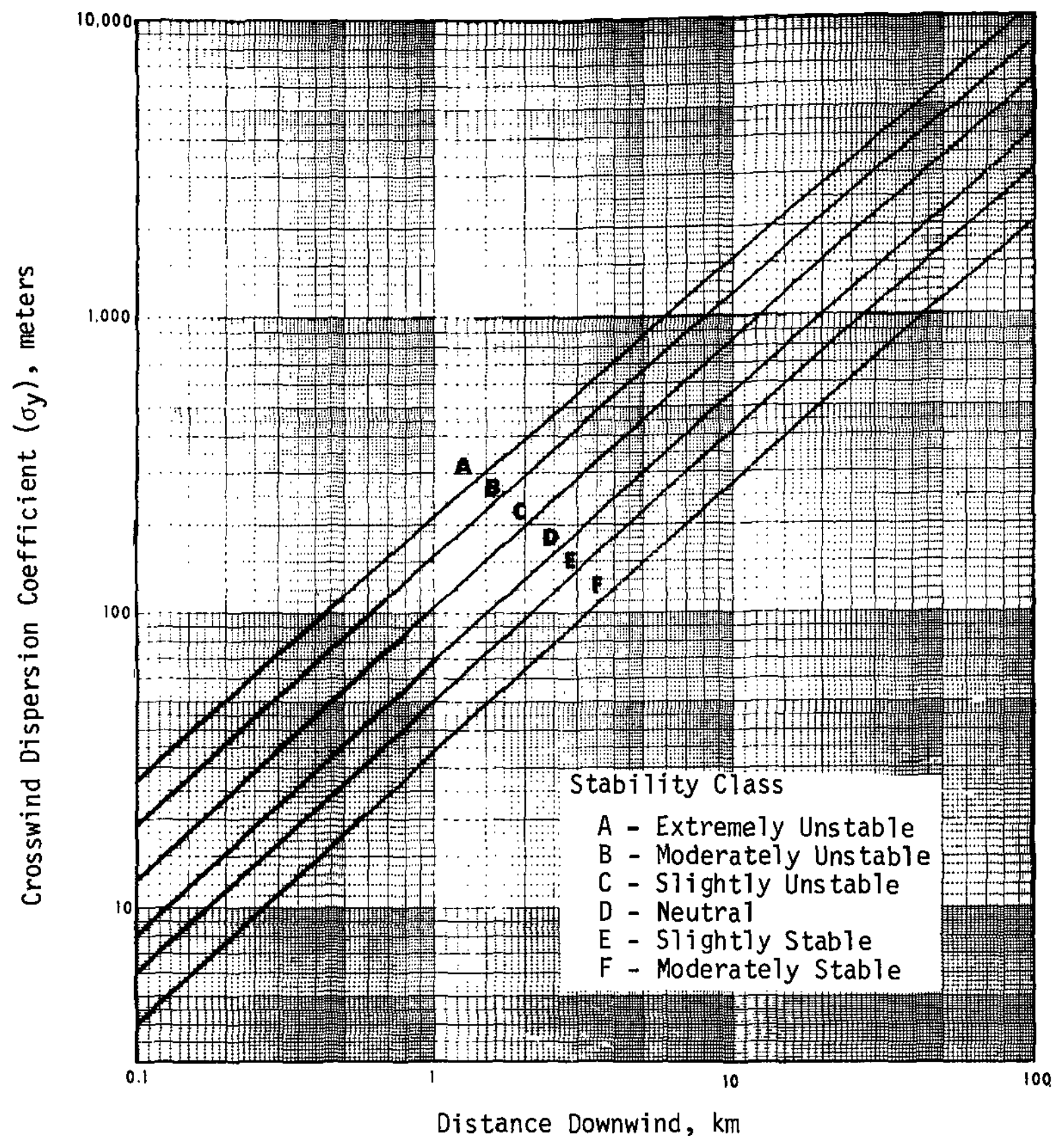

FIGURE 1. Crosswind Dispersion Coefficients Without Meander and Building Wake Effects for Pasquill's Turbulence Types A-F. ${ }^{2}$

For purposes of estimating $\sigma_{y}$ during extremely stable $(G)$ atmospheric stability conditions, without plume meander or other lateral enhancement, the following approximation is appropriate:

$$
\sigma_{y}(G)=\frac{2}{3} \sigma_{y}(F)
$$




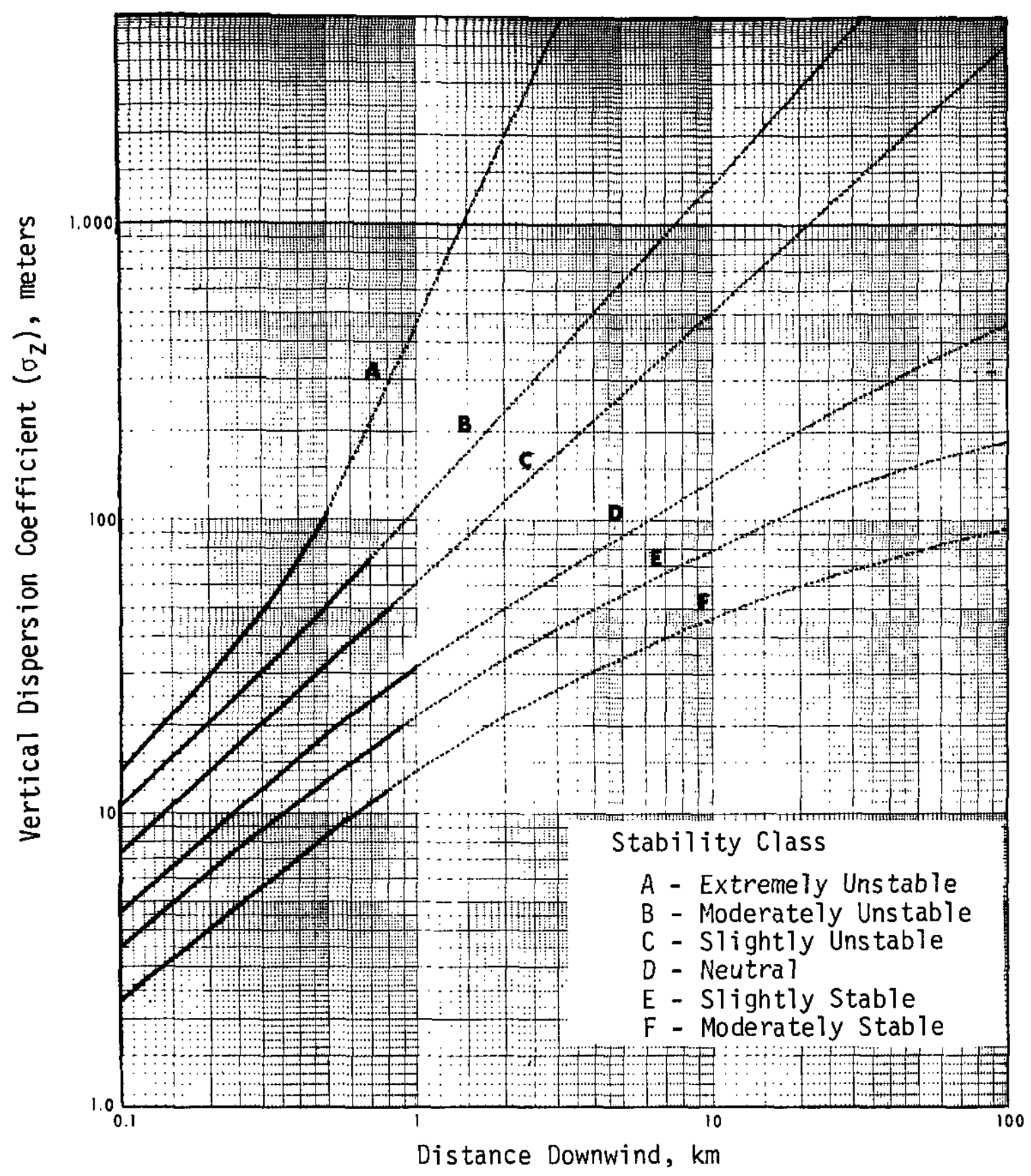

FIGURE 2. Vertical Dispersion Coefficients Without Meander and Building Wake Effects for Pasquill's Turbulence Types A-F. ${ }^{2}$

For purposes of estimating $\sigma_{z}$ during extremely stable (G) atmospheric stability conditions, the following approximation is appropriate:

$$
\sigma_{z}(G)=\frac{3}{5} \sigma_{z}(F)
$$




\section{Releases Through Building Penetrations}

Equations 3 through 5 are for releases lower than 2-1/2 times the height of adjacent solid structures such as vents.

$$
\begin{aligned}
& X / Q=\frac{1}{\bar{u}_{10}\left(\pi \sigma_{y} \sigma_{z}+A / 2\right)} \\
& X / Q=\frac{1}{\bar{u}_{10}\left(3 \pi \sigma_{y} \sigma_{z}\right)} \\
& X / Q=\frac{1}{\bar{u}_{10} \pi \Sigma_{y} \sigma_{z}}
\end{aligned}
$$

where

$$
\begin{aligned}
& \overline{\mathrm{u}}_{10}=\text { the wind speed } 10 \mathrm{~m} \text { above grade elevation of the } \\
& \text { release location, } \mathrm{m} / \mathrm{sec} \\
& A=\text { the smallest vertical-plane cross-sectional area } \\
& \text { of the building, } \mathrm{m}^{2} \\
& \Sigma_{y}=\text { the lateral plume spread with meander and building } \\
& \text { wake effects, } m \text {. Spread is a function of atmospheric }
\end{aligned}
$$

During neutral (Stability Class D) or stable (Stability Class E, F, or G) atmospheric stability conditions when the wind speed at 10 meters is less than $6 \mathrm{~m} / \mathrm{sec}, X / Q$ values should be calculated using Equations 3, 4, and 5. The values from Equations 3 and 4 should be compared and the higher value selected. This value should be compared with the value from Equation 5, and the lower value of these two should be selected as the appropriate $X / Q$ value.

During all other meteorological conditions, i.e., unstable (Stability Class A, B, or C) atmospheric stability and/or 10-meter wind speed of $6 \mathrm{~m} / \mathrm{sec}$ or more, the appropriate $X / Q$ value is the higher value calculated from Equation 3 or 4 . 


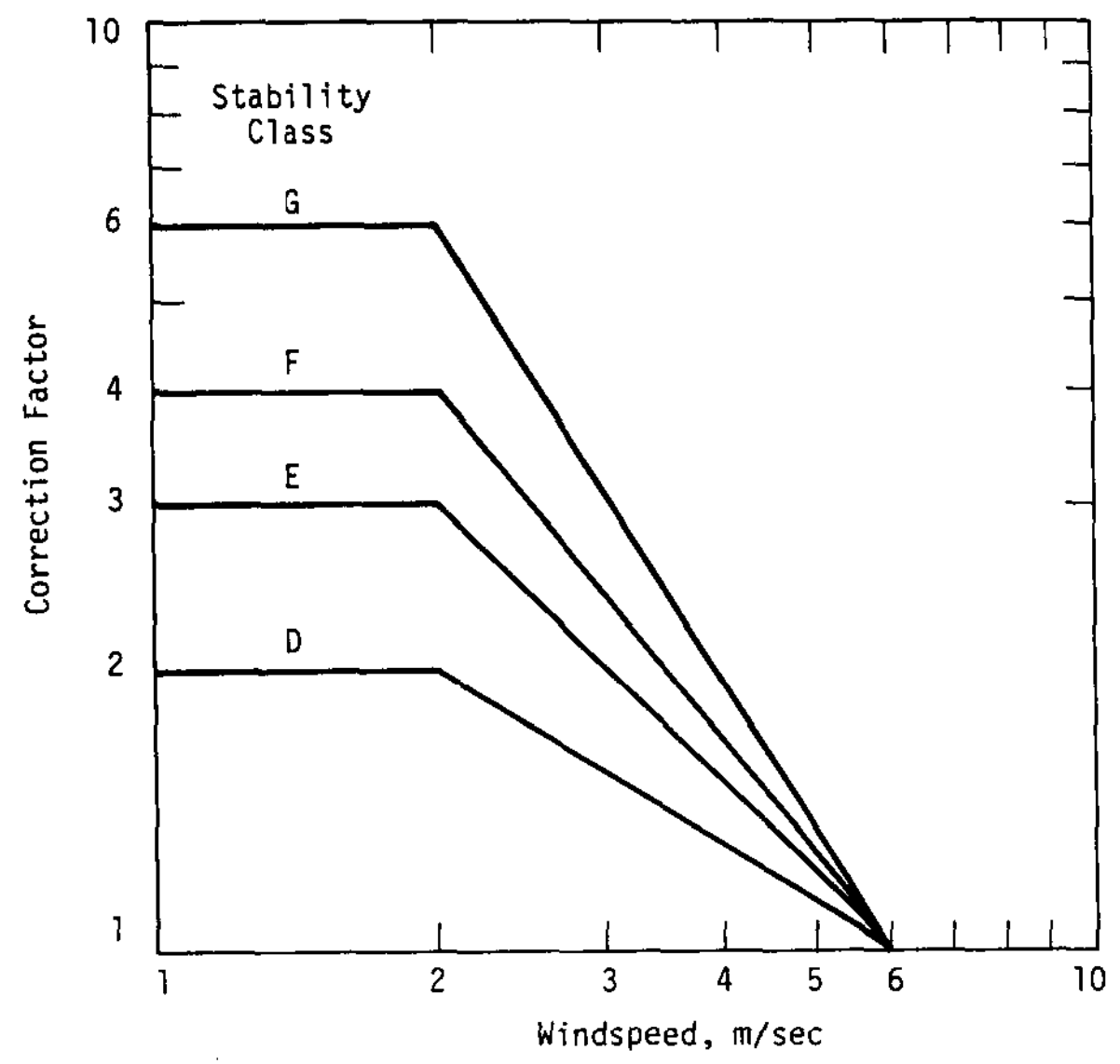

FIGURE 3. Correction Factors for Pasquill-Gifford $\sigma_{y}$ Values for Meander and Building Wake Effects by Atmospheric Stability Class. 


\section{SELECTION OF $\times / Q$ VALUES FOR A POSTULATED RELEASE}

Maximum Sector $x / Q$

The cumulative frequency distribution of relative concentrations for each direction sector is determined using the applicable equations for 42 combinations of six wind speeds and seven stability classes. The relative concentration that is exceeded $0.5 \%$ of the total time is selected as the sector $X / Q$ value. The highest of the 16 sector values is defined as the maximum sector value.

\section{$5 \%$ Overall Site $x / Q$}

The overall cumulative frequency distribution for all directions combined is plotted from the $16 \times 42$ relative concentration values. The $2-\mathrm{hr} \times / \mathrm{Q}$ value that is exceeded $5 \%$ of the time is selected from this plot.

\section{X/Q for Calculating Postulated Events}

The higher value of the above two $X / Q$ values is used in evaluating the postulated event.

\section{INPUT DATA}

\section{Meteorology}

Meteorological data are input as the joint frequency distribution of wind and atmospheric stability. The data consist of: (1) the frequency of occurrence of wind direction into 22.5-degree sectors centered on the 16 compass directions; (2) the atmospheric stability category: one of seven defined by the magnitude of the vertical temperature gradient according to NRC Safety Guide 1.23; ${ }^{3}$ and (3) the wind speed: $0-2,2-4,4-6,6-8,8-12,>12 \mathrm{~m} / \mathrm{sec}$. For assessments of accidental releases at SRP, a joint frequency distribution shown in Table 1 is used. These data are based on the 15-min averaged meteorological data collected at the WJBF-TV tower near SRP for the period 1976-1977. Atmospheric stability is based upon temperature measurements at 10 and $91 \mathrm{~m}$, and wind speed and direction are determined at $62 \mathrm{~m}$. The data are input to the code as an array with seven stability classes, six wind speed classes, and 16 direction sectors. The wind direction data are input as a 16-element array with north defined as the first value and continuing clockwise for the remaining sectors (NNE, $\mathrm{NE}$, ENE, etc.). 
TABLE 1

Joint Frequency Distribution Data for 62-m Level of WJBF-TV Tower - 1376-1977, percent

\begin{tabular}{|c|c|c|c|c|c|c|c|c|c|c|c|c|c|c|c|c|c|c|}
\hline $\begin{array}{l}\text { Stability } \\
\text { Claes }\end{array}$ & $\begin{array}{l}\text { Speed } \\
\text { Range, } \\
\mathrm{m} / \mathrm{sec}\end{array}$ & $N$ & NWE & $N E$ & ENE & $E$ & $E S E$ & $S E$ & SSE & $S$ & SSN & $S W$ & NSW & $N$ & $\mathrm{NWN}$ & $M W$ & $N N W$ & SUN \\
\hline \multirow[t]{2}{*}{ A } & $\begin{array}{l}0-2 \\
2-4 \\
4-6 \\
6-8 \\
8-12 \\
>12\end{array}$ & $\begin{array}{l}0.01 \\
0.06 \\
0.06 \\
0.02 \\
0.0 \\
0.0\end{array}$ & $\begin{array}{l}0.01 \\
0.05 \\
0.08 \\
0.05 \\
0.01 \\
0.0\end{array}$ & $\begin{array}{l}0.02 \\
0.22 \\
0.22 \\
0.13 \\
0.02 \\
0.0\end{array}$ & $\begin{array}{l}0.03 \\
0.29 \\
0.46 \\
0.25 \\
0.08 \\
0.0\end{array}$ & $\begin{array}{l}0.02 \\
0.32 \\
0.43 \\
0.18 \\
0.02 \\
0.0\end{array}$ & $\begin{array}{l}0.04 \\
0.32 \\
0.17 \\
0.07 \\
0.01 \\
0.0\end{array}$ & $\begin{array}{l}0.04 \\
0.30 \\
0.15 \\
0.03 \\
0.01 \\
0.0\end{array}$ & $\begin{array}{l}0.05 \\
0.30 \\
0.25 \\
0.06 \\
0.06 \\
0.0\end{array}$ & $\begin{array}{l}0.06 \\
0.36 \\
0.22 \\
0.10 \\
0.06 \\
0.0\end{array}$ & $\begin{array}{l}0.05 \\
0.53 \\
0.44 \\
0.24 \\
0.06 \\
0.0\end{array}$ & $\begin{array}{l}0.08 \\
0.77 \\
0.65 \\
0.31 \\
0.13 \\
0.01\end{array}$ & $\begin{array}{l}0.07 \\
0.63 \\
0.56 \\
0.32 \\
0.11 \\
0.00\end{array}$ & $\begin{array}{l}0.04 \\
0.58 \\
0.60 \\
0.38 \\
0.35 \\
0.06\end{array}$ & $\begin{array}{l}0.05 \\
0.54 \\
0.45 \\
0.36 \\
0.42 \\
0.09\end{array}$ & $\begin{array}{l}0.03 \\
0.22 \\
0.30 \\
0.16 \\
0.10 \\
0.01\end{array}$ & $\begin{array}{l}0.01 \\
0.13 \\
0.13 \\
0.01 \\
0.0 \\
0.0\end{array}$ & $\begin{array}{l}0.60 \\
5.61 \\
5.16 \\
2.67 \\
1.42 \\
0.18 \\
\end{array}$ \\
\hline & & & & & & & & & & & & & & & & & Total & 15.64 \\
\hline \multirow[t]{2}{*}{ B } & $\begin{array}{l}0-2 \\
2-4 \\
4-6 \\
6-8 \\
8-12 \\
>12\end{array}$ & $\begin{array}{l}0.01 \\
0.04 \\
0.01 \\
0.01 \\
0.00 \\
0.0\end{array}$ & $\begin{array}{l}0.01 \\
0.05 \\
0.04 \\
0.01 \\
0.01 \\
0.0\end{array}$ & $\begin{array}{l}0.01 \\
0.09 \\
0.09 \\
0.03 \\
0.01 \\
0.0\end{array}$ & $\begin{array}{l}0.01 \\
0.05 \\
0.10 \\
0.04 \\
0.02 \\
0.0\end{array}$ & $\begin{array}{l}0.02 \\
0.12 \\
0.11 \\
0.02 \\
0.00 \\
0.0\end{array}$ & $\begin{array}{l}0.01 \\
0.08 \\
0.06 \\
0.01 \\
0.00 \\
0.0\end{array}$ & $\begin{array}{l}0.02 \\
0.08 \\
0.04 \\
0.01 \\
0.00 \\
0.0\end{array}$ & $\begin{array}{l}0.01 \\
0.07 \\
0.05 \\
0.02 \\
0.01 \\
0.00\end{array}$ & $\begin{array}{l}0.02 \\
0.09 \\
0.07 \\
0.04 \\
0.00 \\
0.0\end{array}$ & $\begin{array}{l}0.04 \\
0.13 \\
0.10 \\
0.03 \\
0.01 \\
0.00\end{array}$ & $\begin{array}{l}0.03 \\
0.15 \\
0.12 \\
0.05 \\
0.01 \\
0.01\end{array}$ & $\begin{array}{l}0.04 \\
0.16 \\
0.12 \\
0.09 \\
0.04 \\
0.0\end{array}$ & $\begin{array}{l}0.05 \\
0.16 \\
0.10 \\
0.04 \\
0.09 \\
0.02\end{array}$ & $\begin{array}{l}0.03 \\
0.13 \\
0.10 \\
0.05 \\
0.08 \\
0.01\end{array}$ & $\begin{array}{l}0.01 \\
0.08 \\
0.07 \\
0.05 \\
0.03 \\
0.00\end{array}$ & $\begin{array}{l}0.00 \\
0.07 \\
0.02 \\
0.00 \\
0.0 \\
0.0\end{array}$ & $\begin{array}{l}0.33 \\
1.58 \\
1.20 \\
0.50 \\
0.33 \\
0.05 \\
\end{array}$ \\
\hline & & & & & & & & & & & & & & & & & Total & 3.99 \\
\hline \multirow[t]{2}{*}{ C } & $\begin{array}{l}0-2 \\
2-4 \\
4-6 \\
6-8 \\
8-12 \\
>12\end{array}$ & $\begin{array}{l}0.01 \\
0.03 \\
0.02 \\
0.00 \\
0.0 \\
0.0\end{array}$ & $\begin{array}{l}0.01 \\
0.07 \\
0.03 \\
0.02 \\
0.04 \\
0.0\end{array}$ & $\begin{array}{l}0.01 \\
0.15 \\
0.11 \\
0.03 \\
0.00 \\
0.0\end{array}$ & $\begin{array}{l}0.03 \\
0.11 \\
0.10 \\
0.01 \\
0.01 \\
0.0\end{array}$ & $\begin{array}{l}0.02 \\
0.09 \\
0.10 \\
0.03 \\
0.00 \\
0.0\end{array}$ & $\begin{array}{l}0.03 \\
0.08 \\
0.07 \\
0.01 \\
0.01 \\
0.0\end{array}$ & $\begin{array}{l}0.04 \\
0.07 \\
0.02 \\
0.01 \\
0.0 \\
0.0\end{array}$ & $\begin{array}{l}0.02 \\
0.06 \\
0.05 \\
0.02 \\
0.02 \\
0.0\end{array}$ & $\begin{array}{l}0.03 \\
0.08 \\
0.10 \\
0.04 \\
0.01 \\
0.0\end{array}$ & $\begin{array}{l}0.03 \\
0.11 \\
0.08 \\
0.04 \\
0.01 \\
0.0\end{array}$ & $\begin{array}{l}0.04 \\
0.14 \\
0.11 \\
0.05 \\
0.02 \\
0.01\end{array}$ & $\begin{array}{l}0.05 \\
0.16 \\
0.11 \\
0.05 \\
0.02 \\
0.00\end{array}$ & $\begin{array}{l}0.04 \\
0.15 \\
0.10 \\
0.05 \\
0.05 \\
0.01\end{array}$ & $\begin{array}{l}0.04 \\
0.14 \\
0.07 \\
0.05 \\
0.06 \\
0.01\end{array}$ & $\begin{array}{l}0.01 \\
0.08 \\
0.07 \\
0.04 \\
0.02 \\
0.01\end{array}$ & $\begin{array}{l}0.01 \\
0.04 \\
0.04 \\
0.01 \\
0.0 \\
0.0\end{array}$ & $\begin{array}{l}0.41 \\
1.57 \\
1.19 \\
0.53 \\
0.30 \\
0.01 \\
\end{array}$ \\
\hline & & & & & & & & & & & & & & & & & Total & 4.04 \\
\hline \multirow[t]{2}{*}{ D. } & $\begin{array}{l}0-2 \\
2-4 \\
4-6 \\
6-8 \\
8-12 \\
>12\end{array}$ & $\begin{array}{l}0.06 \\
0.13 \\
0.10 \\
0.06 \\
0.02 \\
0.0\end{array}$ & $\begin{array}{l}0.11 \\
0.27 \\
0.26 \\
0.13 \\
0.10 \\
0.0\end{array}$ & $\begin{array}{l}0.17 \\
0.54 \\
0.55 \\
0.24 \\
0.03 \\
0.0\end{array}$ & $\begin{array}{l}0.14 \\
0.40 \\
0.59 \\
0.44 \\
0.13 \\
0.0\end{array}$ & $\begin{array}{l}0.15 \\
0.39 \\
0.55 \\
0.19 \\
0.03 \\
0.0\end{array}$ & $\begin{array}{l}0.16 \\
0.31 \\
0.40 \\
0.20 \\
0.03 \\
0.0\end{array}$ & $\begin{array}{l}0.14 \\
0.28 \\
0.26 \\
0.14 \\
0.06 \\
0.00\end{array}$ & $\begin{array}{l}0.14 \\
0.27 \\
0.42 \\
0.25 \\
0.10 \\
0.00\end{array}$ & $\begin{array}{l}0.14 \\
0.31 \\
0.39 \\
0.24 \\
0.07 \\
0.0\end{array}$ & $\begin{array}{l}0.18 \\
0.42 \\
0.42 \\
0.22 \\
0.06 \\
0.00\end{array}$ & $\begin{array}{l}0.16 \\
0.55 \\
0.53 \\
0.22 \\
0.04 \\
0.0\end{array}$ & $\begin{array}{l}0.16 \\
0.51 \\
0.40 \\
0.25 \\
0.11 \\
0.01\end{array}$ & $\begin{array}{l}0.19 \\
0.44 \\
0.36 \\
0.25 \\
0.29 \\
0.05\end{array}$ & $\begin{array}{l}0.15 \\
0.38 \\
0.25 \\
0.32 \\
0.60 \\
0.12\end{array}$ & $\begin{array}{l}0.15 \\
0.33 \\
0.36 \\
0.24 \\
0.23 \\
0.03\end{array}$ & $\begin{array}{l}0.08 \\
0.29 \\
0.13 \\
0.05 \\
0.01 \\
0.00\end{array}$ & $\begin{array}{l}2.29 \\
5.81 \\
6.02 \\
3.43 \\
1.89 \\
0.21 \\
\end{array}$ \\
\hline & & & & & & & & & & & & & & & & & Totan 1 & 19.65 \\
\hline \multirow[t]{2}{*}{ E } & $\begin{array}{l}0-2 \\
2-4 \\
4-6 \\
6-8 \\
8-12 \\
>12\end{array}$ & $\begin{array}{l}0.05 \\
0.07 \\
0.15 \\
0.05 \\
0.0 \\
0.0\end{array}$ & $\begin{array}{l}0.08 \\
0.21 \\
0.39 \\
0.19 \\
0.05 \\
0.0\end{array}$ & $\begin{array}{l}0.15 \\
0.51 \\
0.65 \\
0.17 \\
0.0 \\
0.00\end{array}$ & $\begin{array}{l}0.16 \\
0.49 \\
0.85 \\
0.41 \\
0.04 \\
0.0\end{array}$ & $\begin{array}{l}0.19 \\
0.53 \\
0.81 \\
0.15 \\
0.01 \\
0.00\end{array}$ & $\begin{array}{l}0.18 \\
0.46 \\
0.814 \\
0.27 \\
0.01 \\
0.0\end{array}$ & $\begin{array}{l}0.16 \\
0.43 \\
0.99 \\
0.25 \\
0.06 \\
0.0\end{array}$ & $\begin{array}{l}0.14 \\
0.48 \\
1.29 \\
0.74 \\
0.13 \\
0.0\end{array}$ & $\begin{array}{l}0.15 \\
0.51 \\
1.33 \\
0.59 \\
0.04 \\
0.00\end{array}$ & $\begin{array}{l}0.18 \\
0.70 \\
1.53 \\
0.47 \\
0.13 \\
0.0\end{array}$ & $\begin{array}{l}0.19 \\
0.61 \\
1.09 \\
0.51 \\
0.27 \\
0.00\end{array}$ & $\begin{array}{l}0.16 \\
0.54 \\
0.92 \\
0.59 \\
0.14 \\
0.01\end{array}$ & $\begin{array}{l}0.16 \\
0.47 \\
0.84 \\
0.97 \\
0.30 \\
0.01\end{array}$ & $\begin{array}{l}0.14 \\
0.34 \\
0.75 \\
0.95 \\
0.77 \\
0.03\end{array}$ & $\begin{array}{l}0.14 \\
0.37 \\
0.59 \\
0.51 \\
0.15 \\
0.01\end{array}$ & $\begin{array}{l}0.11 \\
0.23 \\
0.41 \\
0.15 \\
0.01 \\
0.00\end{array}$ & $\begin{array}{r}2.31 \\
6.96 \\
13.46 \\
6.88 \\
2.12 \\
0.00 \\
\end{array}$ \\
\hline & & & & & & & & & & & & & & & & & Total & 31.81 \\
\hline \multirow[t]{2}{*}{$F$} & $\begin{array}{l}0-2 \\
2-4 \\
4-6 \\
6-8 \\
8-12 \\
>12\end{array}$ & $\begin{array}{l}0.03 \\
0.09 \\
0.11 \\
0.08 \\
0.00 \\
0.0\end{array}$ & $\begin{array}{l}0.02 \\
0.15 \\
0.20 \\
0.15 \\
0.01 \\
0.0\end{array}$ & $\begin{array}{l}3.06 \\
0.23 \\
0.37 \\
0.14 \\
0.01 \\
0.0\end{array}$ & $\begin{array}{l}0.06 \\
0.15 \\
0.5 .4 \\
0.30 \\
0.01 \\
0.0\end{array}$ & $\begin{array}{l}0.10 \\
0.15 \\
0.44 \\
0.42 \\
0.04 \\
0.0\end{array}$ & $\begin{array}{l}0.08 \\
0.29 \\
0.60 \\
0.24 \\
0.00 \\
0.0\end{array}$ & $\begin{array}{l}0.08 \\
0.34 \\
0.44 \\
0.14 \\
0.01 \\
0.0\end{array}$ & $\begin{array}{l}0.06 \\
0.26 \\
0.52 \\
0.36 \\
0.03 \\
0.0\end{array}$ & $\begin{array}{l}0.06 \\
0.34 \\
0.84 \\
0.54 \\
0.03 \\
0.0\end{array}$ & $\begin{array}{l}0.08 \\
0.44 \\
0.94 \\
0.59 \\
0.02 \\
0.0\end{array}$ & $\begin{array}{l}0.11 \\
0.39 \\
0.79 \\
0.48 \\
0.11 \\
0.02\end{array}$ & $\begin{array}{l}0.08 \\
0.31 \\
0.73 \\
0.53 \\
0.10 \\
0.0\end{array}$ & $\begin{array}{l}0.08 \\
0.22 \\
0.67 \\
0.60 \\
0.07 \\
0.0\end{array}$ & $\begin{array}{l}0.07 \\
0.15 \\
0.41 \\
0.12 \\
0.06 \\
0.00\end{array}$ & $\begin{array}{l}0.05 \\
0.14 \\
0.34 \\
0.34 \\
0.02 \\
0.0\end{array}$ & $\begin{array}{l}0.04 \\
0.13 \\
0.15 \\
0.18 \\
0.02 \\
0.0\end{array}$ & $\begin{array}{l}1.07 \\
3.87 \\
8.10 \\
5.60 \\
0.55 \\
0.02 \\
\end{array}$ \\
\hline & & & & & & & & & & & & & & & & & Total & 19.21 \\
\hline G & $\begin{array}{l}0-2 \\
2-4 \\
4-6 \\
6-8 \\
8-12 \\
>12\end{array}$ & $\begin{array}{l}0.03 \\
0.03 \\
0.05 \\
0.01 \\
0.01 \\
0.0\end{array}$ & $\begin{array}{l}0.02 \\
0.02 \\
0.06 \\
0.04 \\
0.00 \\
0.0\end{array}$ & $\begin{array}{l}0.03 \\
0.08 \\
0.08 \\
0.04 \\
0.00 \\
0.0\end{array}$ & $\begin{array}{l}0.03 \\
0.08 \\
0.17 \\
0.14 \\
0.0 \\
0.0\end{array}$ & $\begin{array}{l}0.03 \\
0.08 \\
0.12 \\
0.22 \\
0.02 \\
0.0\end{array}$ & $\begin{array}{l}0.03 \\
0.10 \\
0.17 \\
0.09 \\
0.02 \\
0.0\end{array}$ & $\begin{array}{l}0.04 \\
0.08 \\
0.11 \\
0.04 \\
0.00 \\
0.0\end{array}$ & $\begin{array}{l}0.03 \\
0.10 \\
0.12 \\
0.07 \\
0.01 \\
0.0\end{array}$ & $\begin{array}{l}0.02 \\
0.09 \\
0.23 \\
0.15 \\
0.01 \\
0.0\end{array}$ & $\begin{array}{l}0.05 \\
0.11 \\
0.30 \\
0.14 \\
0.02 \\
0.0\end{array}$ & $\begin{array}{l}0.01 \\
0.10 \\
0.22 \\
0.10 \\
0.02 \\
0.0\end{array}$ & $\begin{array}{l}0.02 \\
0.08 \\
0.28 \\
0.08 \\
0.01 \\
0.0\end{array}$ & $\begin{array}{l}0.03 \\
0.10 \\
0.20 \\
0.09 \\
0.00 \\
0.0\end{array}$ & $\begin{array}{l}0.01 \\
0.06 \\
0.13 \\
0.08 \\
0.00 \\
0.0\end{array}$ & $\begin{array}{l}0.02 \\
0.08 \\
0.10 \\
0.05 \\
0.00 \\
0.0\end{array}$ & $\begin{array}{l}0.03 \\
0.03 \\
0.09 \\
0.09 \\
0.01 \\
0.0\end{array}$ & $\begin{array}{l}0.43 \\
1.21 \\
2.44 \\
1.45 \\
0.15 \\
0.0 \\
\end{array}$ \\
\hline
\end{tabular}




\section{Topography}

Topographical data are determined from a topographical map for each of the 16 sectors. The procedure is to overlay the release point with a grid consisting of the 16 sectors and the plant boundary. The highest topographic feature in feet above MSL within the area defined by the sector and boundary is used for a conservative estimate of the effects of topography on release behavior. These topographic data are input to the computer code as a 16-element array with the first value representing the topography in the $S$ sector and continuing clockwise through the remaining sectors ( $S S W, S W, W S W$, etc.). The grade elevation of the releasing stack or building is also an input to the code.

\section{Distance to Boundary}

According to Regulatory Guide $1.145,^{1}$ the $X / Q$ values for each significant release point should be calculated for each wind direction sector at an appropriate exclusion area boundary distance and outer low population zone (LPZ) boundary distance.

For the SRP applications, the distance to the exclusion area boundary or the low population zone boundary is determined as the minimum distance in miles from the source location (stack or the nearest point on the building) to the SRP boundary for the 45 degree sector centered on the compass direction of interest. These data are input to the computer code as a 16-element array with the first value representing the distance to the southern boundary and continuing in a clockwise direction for the remaining sectors.

For the stack releases, the maximum ground-level concentrations in a sector may occur beyond the exclusion area boundary distance or outer $L P Z$ boundary distance. Therefore, $X / Q$ calculated should be in each sector at each boundary distance and at various distances beyond the exclusion area boundary distance to determine the maximum relative concentration for each sector.

\section{Example of Data Input} code.

Table 2 summarizes the input required to execute the computer 
TABLE 2

Card Format of Input Data

$\begin{array}{cccc}\text { Card } & \begin{array}{c}\text { Variable } \\ \text { Nome }\end{array} & \text { Type } & \text { Format } \\ \text { Number } & \text { RLSTYP } & \mathrm{R} * 8 & \text { A8 } \\ \text { Card 1 } & \text { R } & \end{array}$

RLSTYP = STAKFUM: Stack release with fumigation STAKNFUM: Stack release without fumigation BLDGVENT: Building vent release

Card 2

NRUNS

$I * 2 \quad$ I 2

Card 3

$X X X X$

$\mathrm{R} * 8 \quad \mathrm{~A} 8$

If XXX is blank, Cards 4, 5, and 6 are not required. Computations default to input data pertaining to the facility.

Card 4

$$
\operatorname{DIST}(I), I=1,16 \quad R * 4 \quad 16 F 5.2
$$

The array DIST contains the minimum distance in miles from the source location to plant boundary for the 45-degree sector centered on the compass direction of interest (Reference 1, Page 2, Paragraph 1.2). DIST (1) is towards south, DIST (2) is towards SSW, etc. It may be necessary to perform calculation for distances beyond plant boundary to determine where the maximum ground level concentration occurs. (Reference 1, Page 2, Paragraph 1.2).

Card 5

$$
\text { TOP (I), I=1,16 R*4 16F5.1 }
$$

The array TOP contains the maximum elevation (feet above MSL) between the proposed source and the plant boundary. The topographical data are given for sixteen 22.5 degree sectors centered on $\mathrm{S}, \mathrm{SSW}, \mathrm{SW}, \ldots, \mathrm{SE}, \mathrm{SSE}$. The directions are relative to the point of release.

Card 6

$$
\mathrm{H}, \mathrm{B}, \mathrm{HLID} \quad \mathrm{R} * 4 \quad 2 \mathrm{~F} 5.1, \mathrm{~F} 6.1
$$

$H$ is release height in meters. $B$ is vent release height in meters. HLID is average mixing depth in meters.

Card 7 (Card 4
if $x \times x \times b I$ ank)

A

$\mathrm{R}^{*} 4$

F 10.2

A is the smallest vertical plane cross-sectional area of the building in $\mathrm{m}^{2}$. This card is on $1 \mathrm{y}$ required when RLSTYP $=$ BLDGVENT. 
OUTPUT

The output of the computer code includes:

1. The established joint frequency distribution of wind and atmospheric stability.

2. Tabulated and plotted cumulative frequency distribution of relative concentration $(X / Q)$ for each wind direction sector (to determine the sector $X / Q$ ).

3. The $X / Q$ that exceeded $0.5 \%$ of the time linearly interpolated from tabulated data for each sector.

4. Summary of the $X / Q$ values for all 16 sectors.

5. Plotted cumulative frequency of combined relative concentration $(X / Q)$ to determine the $5 \%$ overall site $X / Q$ value.

6. The $5 \%$ overall site $X / Q$ value, which was 1 inearly interpolated from tabulated data.

7. The $X / Q$ value selected for the evaluation of postulated events. Figures 4 through 6 show typical output. 
FIGURE 4. Computer Output for Sector 1 (South)

a. Individual $X / Q$ Values Used to Determine Frequency Distribution SECTCA= L: CIST=18.BEKN E EFFECTIVE SIACK HEIGLTITO.28N

\begin{tabular}{|c|c|c|c|c|c|c|c|c|c|}
\hline 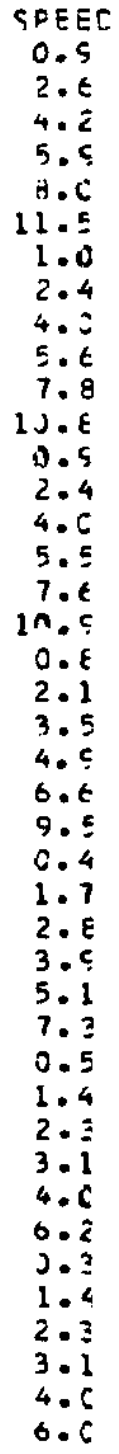 & $\begin{array}{l}51.9 \\
2638.2 \\
2638.2 \\
2638.2 \\
2639.2 \\
2638.2 \\
2638.2 \\
2029.7 \\
2029.7 \\
2329.7 \\
2029.7 \\
2025.7 \\
2329.7 \\
1439.4 \\
1439.4 \\
1439.4 \\
1439.4 \\
1439.4 \\
1439.4 \\
554.9 \\
554.5 \\
554.9 \\
554.5 \\
954.5 \\
554.5 \\
714.5 \\
714.5 \\
714.5 \\
714.9 \\
714.5 \\
714.5 \\
476.0 \\
476.0 \\
476.9 \\
476.5 \\
476.0 \\
476.0 \\
317.4 \\
317.4 \\
317.4 \\
317.4 \\
317.4 \\
317.4\end{array}$ & 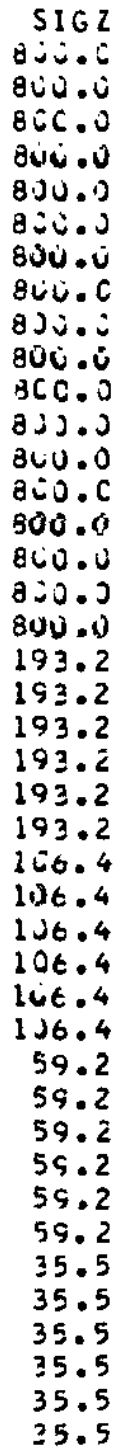 & 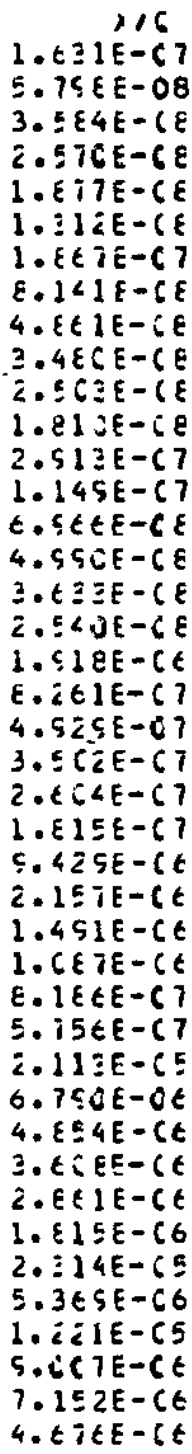 & 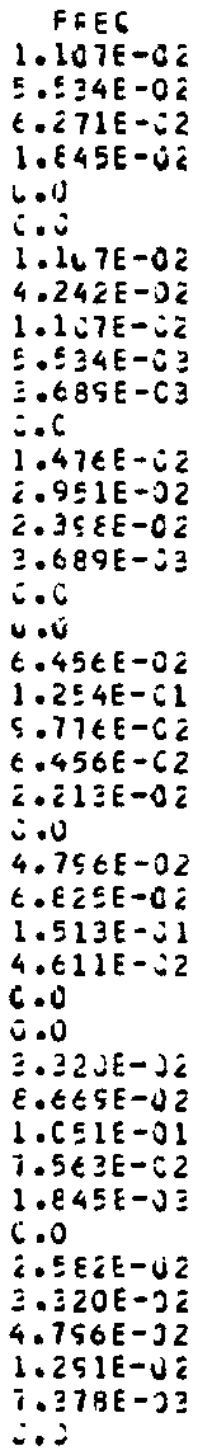 & $\begin{array}{l}\text { STA } \\
1 \\
1 \\
1 \\
1 \\
1 \\
1 \\
2 \\
2 \\
2 \\
2 \\
2 \\
2 \\
2 \\
3 \\
2 \\
3 \\
3 \\
3 \\
4 \\
4 \\
4 \\
4 \\
4 \\
4 \\
5 \\
5 \\
5 \\
5 \\
5 \\
5 \\
6 \\
6 \\
6 \\
6 \\
6 \\
6 \\
7 \\
7 \\
7 \\
7 \\
7 \\
7\end{array}$ & IC & $\begin{aligned} \text { SFEEC } \\
1 \\
2 \\
2 \\
4 \\
5 \\
6 \\
1 \\
2 \\
2 \\
4 \\
5 \\
6 \\
1 \\
2 \\
3 \\
4 \\
5 \\
6 \\
1 \\
2 \\
3 \\
4 \\
5 \\
6 \\
1 \\
2 \\
2 \\
4 \\
5 \\
6 \\
1 \\
2 \\
2 \\
4 \\
5 \\
6 \\
1 \\
2 \\
3 \\
4 \\
5 \\
6\end{aligned}$ & I C & $\begin{array}{c}\text { SECTCR } \\
1 \\
1 \\
1 \\
1 \\
1 \\
1 \\
1 \\
1 \\
1 \\
1 \\
1 \\
1 \\
1 \\
1 \\
1 \\
1 \\
1 \\
1 \\
1 \\
1 \\
1 \\
1 \\
1 \\
1 \\
1 \\
1 \\
1 \\
1 \\
1 \\
1 \\
1 \\
1 \\
1 \\
1 \\
1 \\
1 \\
1 \\
1 \\
1 \\
1 \\
1 \\
1\end{array}$ \\
\hline
\end{tabular}

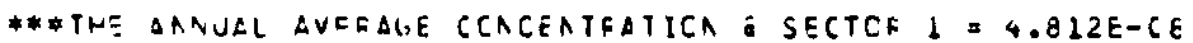


FIGURE 4. Continued

b. Tabular Values of Cumulative Frequency Distribution of $X / Q$

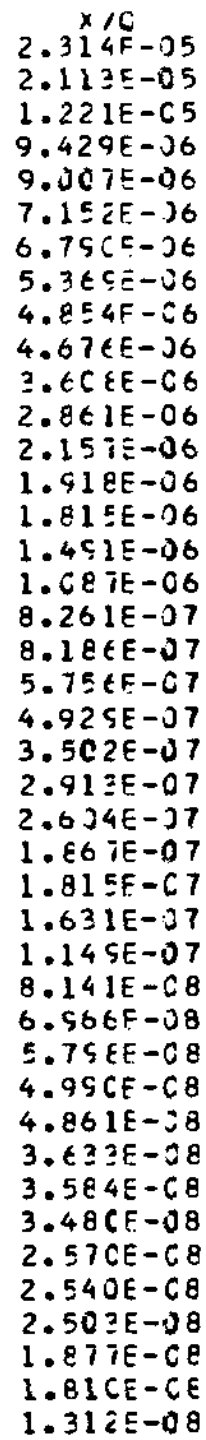

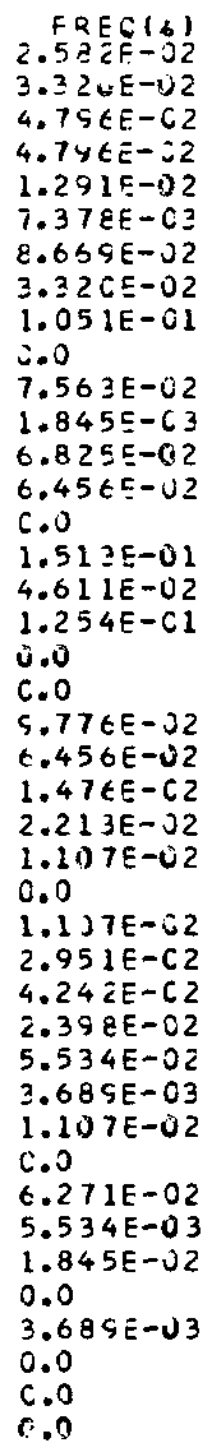

6. 9

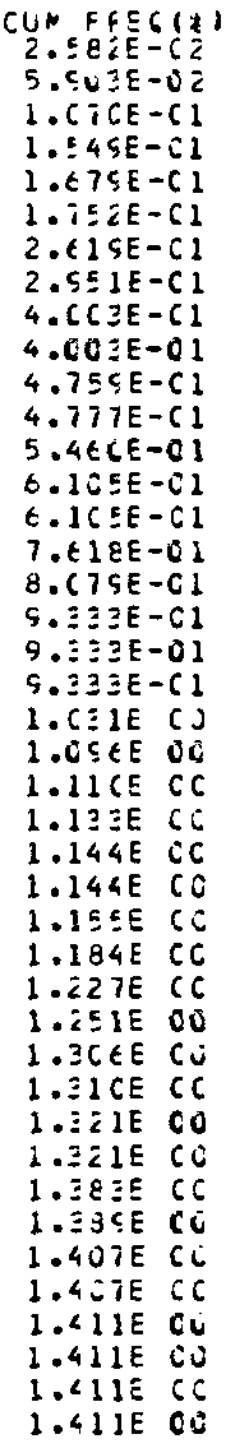

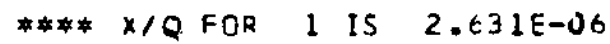

*** Xo value of a sectcr that is exceecec 0.gz cf

THE TOTAL TIMF IS UEFINEC AS THE SECTCR X/G VALUE. 
FIGURE 4. Continued

c. X/Q Value Used in Accident Analyses for Each Sector

\section{summary: the 16 SECTCR X/O value}

\begin{tabular}{|c|c|}
\hline $\begin{array}{l}1 \\
2 \\
3 \\
4 \\
5 \\
6 \\
7 \\
8 \\
9 \\
16 \\
11 \\
12 \\
13 \\
14 \\
15 \\
16\end{array}$ & $\begin{array}{l}2 . t 31 E-C E \\
7.223 E-C 6 \\
9.534 E-C E \\
1.50 E E-C 5 \\
1.71 C E-C 5 \\
1 . E Z 3 E-C 5 \\
1.38 S E-C 5 \\
1.38 E E-C 5 \\
1 . C C E E-C 5 \\
2 . C 39 E-C 5 \\
1.3 E E E-C 5 \\
1.3 E 7 E-C 5 \\
1.324 E-C 5 \\
4 . E E C E-C 6 \\
9.3 E Z E-C 6 \\
0.3 C C E-C 6\end{array}$ \\
\hline
\end{tabular}




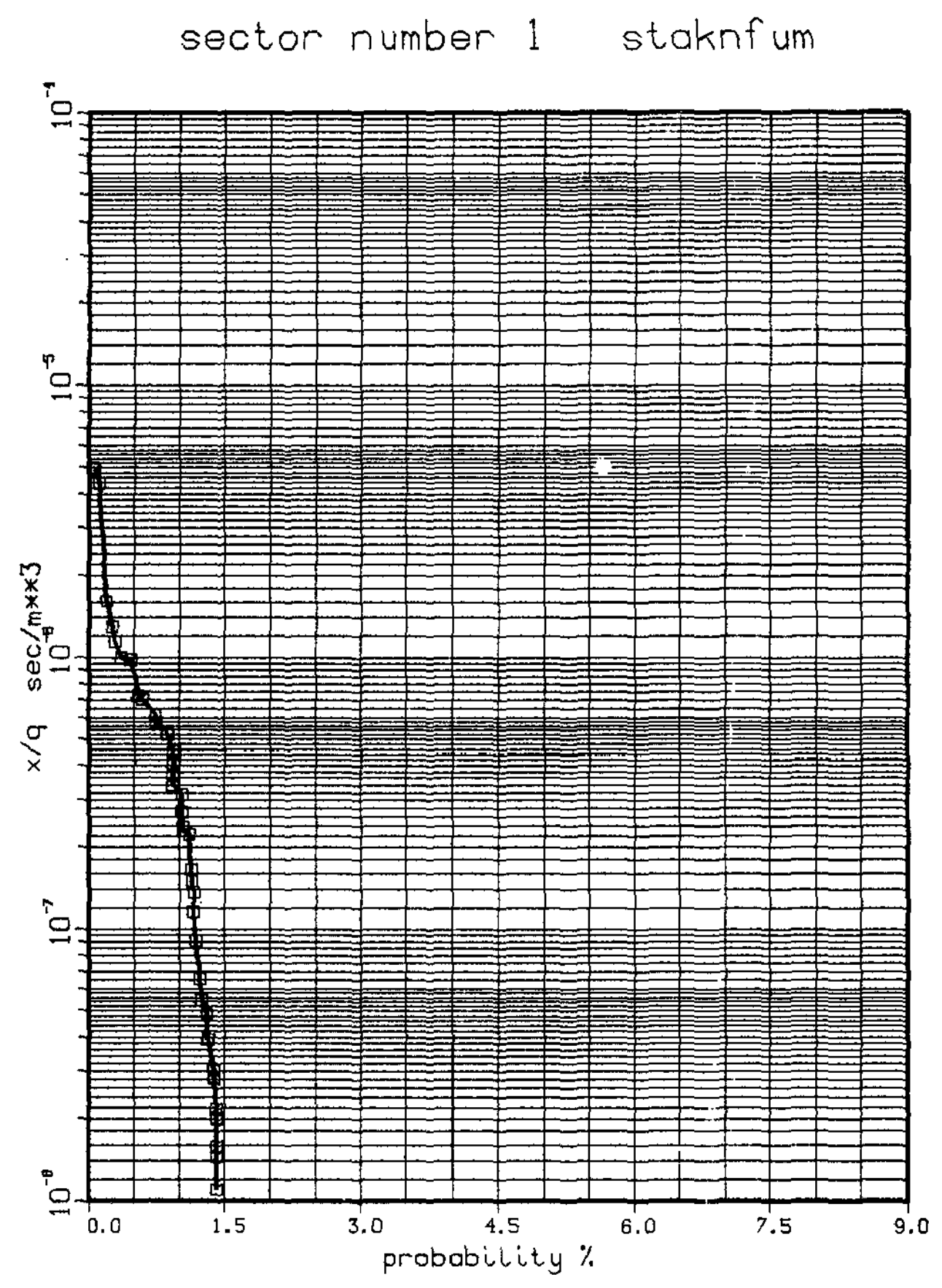

FIGURE 5. Computer Plots for Sector 1 (South). 


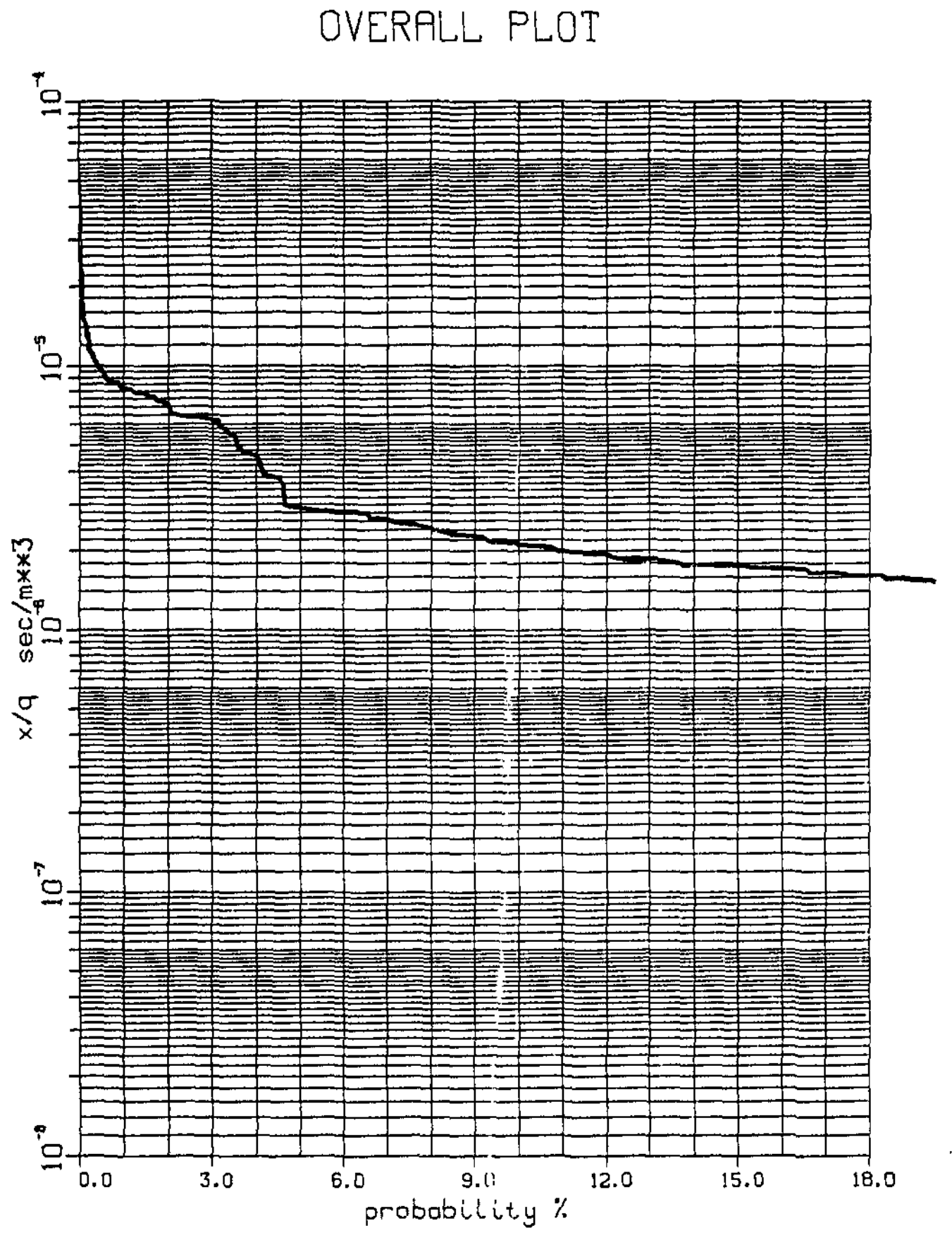

FIGURE 6. Computer Plot for $A 11 \times / Q$ Values Irrespective of Direction Sector. 


\section{REFERENCES}

1. Atmospheric Dispersion Mode1 for Potential Accident Consequence Assessment at Nuclear Power Plants. Regulatory Guide 1.145, US Nuclear Regulatory Commission, Washington, DC (1979).

2. D. B. Turner. A Workbook of Atmospheric Dispersion Estimates. Public Health Service Publication No. 999-AP 26. US Dept. of Health, Education, and Welfare, Cincinnati, $\mathrm{OH}$ (1969).

3. Safety Guide for Water Cooled Nuclear Power Plants. Safety Guide 1.23, "Onsite Meteorological Program."

USAEC Division of Reactor Standards, Washington, DC (1972). 